\title{
GEOLOGICAL-GEOPHYSICAL STUDY FOR THE DESIGN OF A HAZARDOUS WASTE LANDFILL IN ALBANIA
}

\author{
Beqiraj A. ${ }^{1}$, Alikaj P. ${ }^{1}$, Lamaj M. ${ }^{2}$, Muceku Y. ${ }^{2}$, Çanga B. ${ }^{1}$, and Leka G. ${ }^{2}$ \\ ${ }^{1}$ Faculty of Geology and Mining, ae@beqiraj.yahoo.com \\ ${ }^{2}$ Geological Survey of Albania
}

\begin{abstract}
Industrial wastes in Albania belong to four main groups: i) wastes from the industrial hot spots, ii) wastes from the old chemical storages, iii) wastes from mining and ore processing and iiii) wastes from present and future industries. The landfill for hazardous waste is intended as a facility to enable the clean-up of old mostly abandoned industrial sites (the hot spots and other sites), storages of obsolete chemicals and treat and dispose of hazardous waste presently generated in Albanian industry. The technical design of the landfill was anticipated by complex geological study including the geological, geophysical, geotechnical and hydrogeological surveys. All the above surveys aimed to find the best clay terrains with suitable geotechnical and hydrogeological features for the landfill design.
\end{abstract}

Key words: hot spot, hydromonitoring, electrometry.

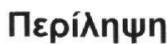

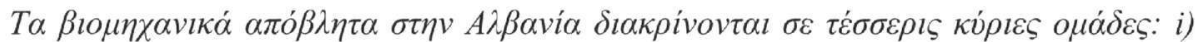

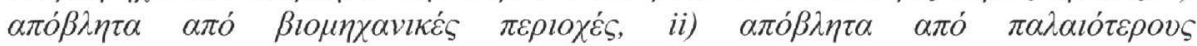

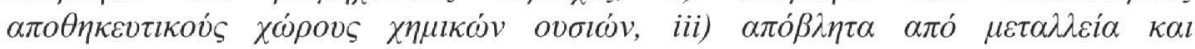
$\varepsilon \pi \varepsilon \xi \varepsilon \rho \gamma \alpha \sigma i \alpha \mu$

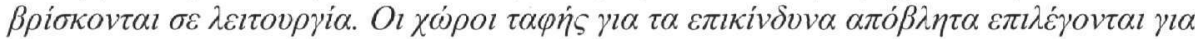

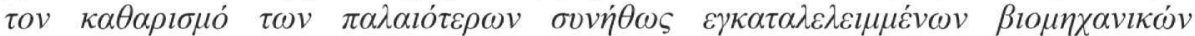

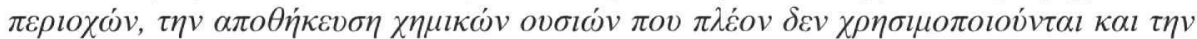

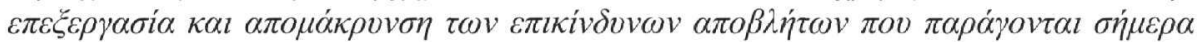

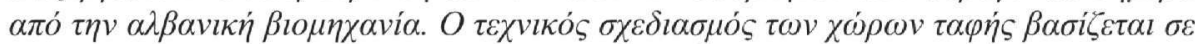

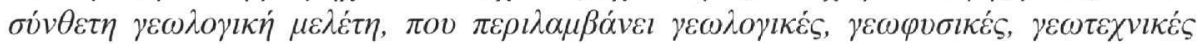

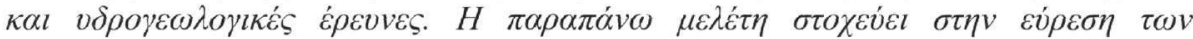

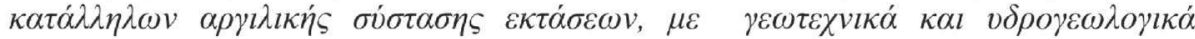

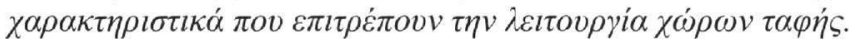

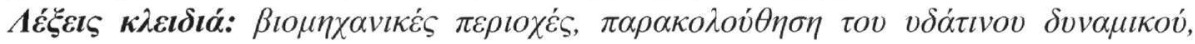
$\eta \lambda \varepsilon \kappa \tau \rho о \mu \varepsilon \tau \rho i \alpha$.

\section{Introduction}

In Albania occur about nine main hot spots that represents historical hazardous waste of the former industry (Fig. 1). It was considered indispensable their accomodation in a landfill in order to 
minimize their negative environmental impact in the regions where they occur (Matache et al. 2004). This paper presents the first experience of the geological-geophysical studies for the design of a hazardeous landfill in Albania. The whole study consists of three phases, beginning with geological survey (first phase), followed by geological-geophysical study (second phase and, concluding with geotechnical study and hydromonitoring (third phase).

\section{Methods}

The geological survey of the first phase aimed to find the mostly clayey zones which represent the geologically sutable areas for the landfill site because of their perfect impermeability. In fact, the most suitable terrains belong to Miocene-Pliocene clays which occur mainly in the Jonian zone and western Adriatic depression of Albania. At the end of this phase, ten sites were proposed. A more detailed geological-geophysical study was commited during the second phase that focused on three sites: Kutallia, Helmesi and Zharresi. The geophysical methods helped to clarify: i) the possible heterogeneities across the general geological structure (ERP method) and ii) the variation of the lithology with depth (VES method) (Bray et al. 2006). The third phase was focused on the Zharresi site which was found to be more suitable from the geological, economic, technical and operational point of view. Finally, the soil investigation works and hydromonitoring of the ground water levels found that the clays of Zharresi site are suitable for the landfill design.

\section{Results and Discussion}

\subsection{Phase 1. Geological survey}

The geological survey aimed to find the geologically sutable areas, that is, the mostly clayey zones (Hyseni 1995, Beqiraj et al. 2006). Because the landfill basement must be impermeable, two priority geological and hydrologeological terrains were considered: Miocene-Pliocene clay and Cretaeous - Paleogene flysch formations. The first type represents the highest priority because clays are i) practically water impermeable, ii) thick in section, iii) present in the low hill terrain and iiii) soft in digging and processing. At the end of this survey, 42 geologically suitable areas were identified, most of them Type I areas. Before the subsequent topographical study some of the areas were excluded because of very distant location from acceptable roads and therefore technically and logistically too difficult.

\subsubsection{Topographical survey}

The possible areas resulting from the geological survey were studied in detail on maps 1:25.000 in order to find possible sites with the following criteria: i) area of $8-10$ hectares of reasonable flat area for the landfill facility; ii) the site should not be in the plains, but somewhat elevated; iii) the site should not be crossed by any surface waters; iiii) the site should be reasonably close to existing acceptable road. Therefore the number of was not very large. Some. As a result of topographical screening, 70 possible sites were identified within the above 42 geologically suitable areas. The study followed by screening with basic (Environmental, Technical and operational, Geological and hydrogeological) criteria.

\subsubsection{Geological criteria}

Between the geological criterias, the most principle ones were considered Lee and Jones-Lee (1996), A i) impermeable clay formation. Preferred is homogeneous clay (priority 1) acceptable is also flysch with impermeable clay (priority 2), the occurring depth of the layer should be at least 5 $\mathrm{m}$, preferable more than $10 \mathrm{~m}$; ii) the ground water table (maximum) should be at least $5 \mathrm{~m}$ below the surface in order to establish a landfill of $3-4 \mathrm{~m}$ depth; iii) the area should not be at fault areas, seismic impact zones and unstable areas; iiii) the area should not be in risk of flooding at any conditions. 
Applying the last criteria (geological criteria included), a lot of plains were excluded because they are mostly cultivated or are placed on the main aquifers. The result of the screening with the above listed criteria was approximately 20 sites which were inspected on site.

\section{ADMINISTRATIVE MAP OF ALBANIA WITH HOT SPOTS AND ZHARRESI LANDFILL SITE}

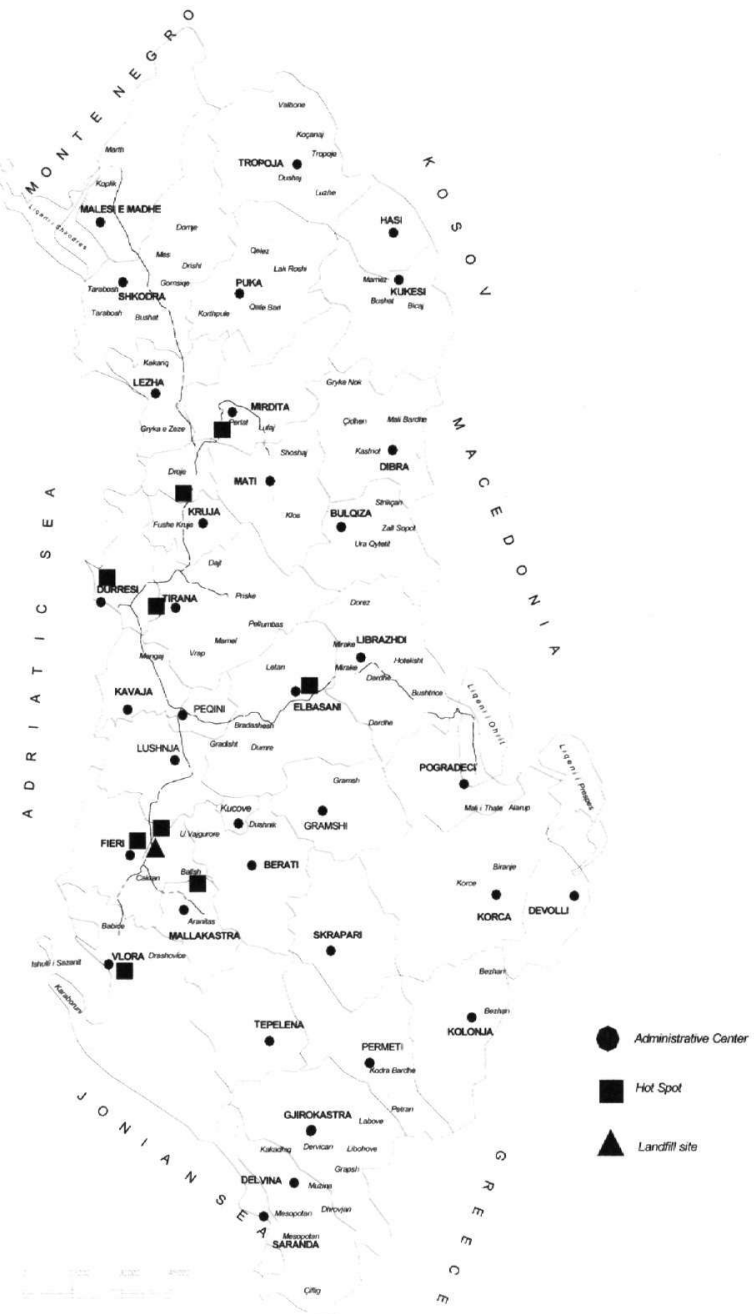

Figure 1 - Administrative map of Albania with hot spots and Zharresi landfill site

\section{Site inspection}

The goal of the inspection was to verify the findings and details of the maps and evaluate: i) the actual topography and details such as houses, surface waters, agriculture; ii) evaluate the possible impact on the surrounding; iii) evaluate the access roads and other infrastructures. After the site inspection, the following 10 sites were presented: Berxull (Tirane), Vora (Tirane), Manza (Durres), Peza e Vogel (Tirane), Helmesi (Kavaje), Divjaka (Lushnje), Kutallia (Berat), Papri 
(Elbasan), Cerrik (Elbasan), Zharresi (Fier). The preliminary evaluation made by the project, that considered all the above criteria by weight, concluded that the best three sites for the hazardeous waste landfill were: 1) Helmasi, 2) Kutallia, 3) Patos-Marinëza.

\subsection{Phase 2. Geological - Geophysical study}

A more detailed geological study was commited on the above three sites aimed to solve the following duties:

a) the investigation of the possible heterogeneities and the tectonic features of the area; b) the study of the Quaternary cover thickness and its relationship with the surrounding rocks; c) the study of slope erosion and the visual slope slides; d) the observation of the possible water-springs and wet areas; e) the observation of the surface waters (streams, water-basins, etc); f) the observation of the geomorphological features (relief, shape, slope steepness, erosional sections, etc.).

The geophysical surveys helped in the solution of the above mentioned duties, mostly in the first two ones [3]. They included the geoelectrical investigations with the Electrical Resistivity Profiling (ERP) and the Vertical Electrical Sounding (VES) methods. These methods were applied to study: i) the possible heterogeneities across the general geological structure (ERP method) and ii) the variation of the lithology with depth (VES method).

a) Resistivity Profiling on Line 2
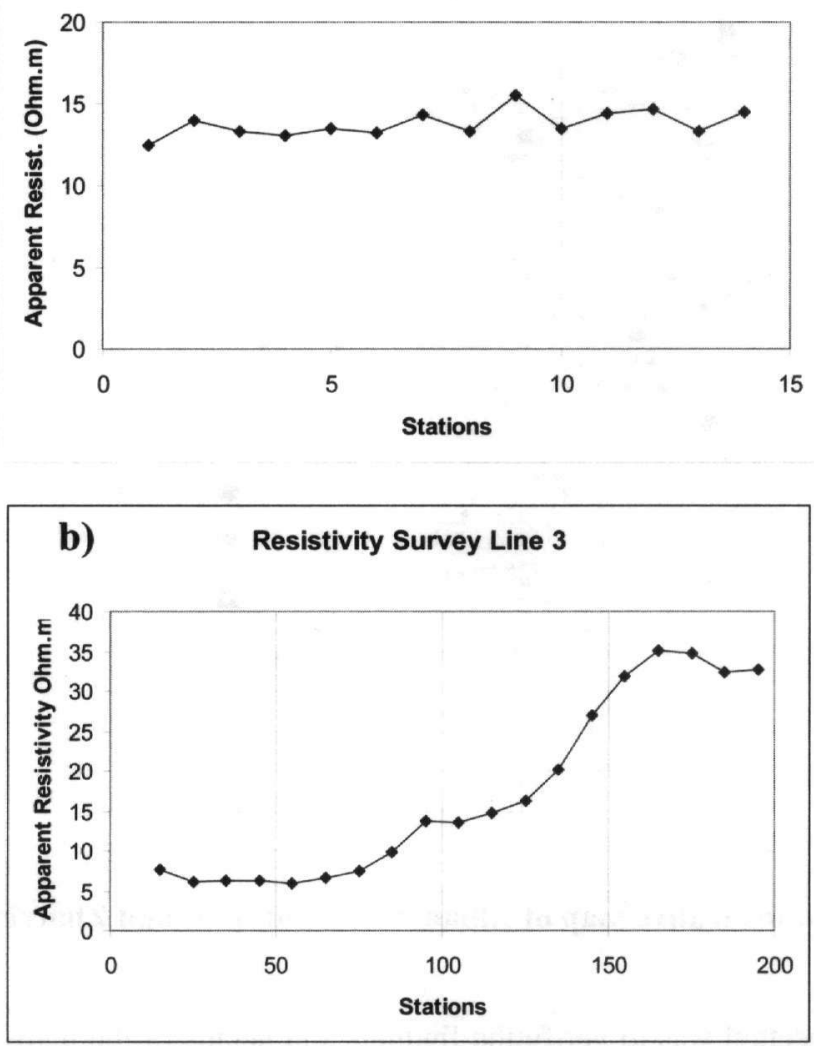

Figure 2 - Geoelectrical profiling with a Wenner Array $(a=10 \mathrm{~m})$ a) Kutalli site and b) Zharresi site 
The ERP method was conducted with a Wenner array (AMNB) with an equidistance $\mathrm{a}=10 \mathrm{~m}$ that provides a depth of investigation up to $8 \mathrm{~m}$ from the surface (Fig. 2). The VES measurements were carried out with a portable transmitter type IPC-8/250W and a digital receiver RDC-10, both produced by the Canadian company Scintrex. The current electrodes spacing from $\mathrm{AB} / 2=1.5 \mathrm{~m}$ up to $\mathrm{AB} / 2=40 \mathrm{~m}$ provided a depth of investigation from $0.6 \mathrm{~m}$ to $20 \mathrm{~m}$.

Helmesi site. The interpretations of the soundings indicate that the silty diluvium cover thickness varies from $0.5 \mathrm{~m}$ to $2.2 \mathrm{~m}$. The resistivity values vary between 4 and $9 \mathrm{Ohm} . \mathrm{m}$ which indicates that the underneath clay environment is quite homogeneous, at least up to the depth of investigation

Site Zharresi. The good quality clay layers, which belong to the NE side of the valley, are characterized by specific resistivity values below $15 \mathrm{Ohm} . \mathrm{m}$. The values below $25 \mathrm{Ohm}$.m are generally considered as mostly clay formations. For higher values, in the range $25-40 \mathrm{Ohm} . \mathrm{m}$, the amount of sand in the clay is markedly increased.

Kutalli site. From the top to the bottom of the section, three geological units are distinguished based on the resistivity values, as shown below: i) alluvial - deluvial cover, $19-24.5 \mathrm{Ohm} . \mathrm{m}$; ii) altered clay, $12.5-16.2 \mathrm{Ohm} . \mathrm{m}$; iii) basement clay, $9.2-10.2 \mathrm{Ohm} . \mathrm{m}$. The narrow range of the resistivity values variation indicates the presence of a good clay environment, at least up to the depth of investigation.

Zharresi site. At the end of this phase was found that, to some extents, all the above sites are geologically suitable for the landfill design. The Zharresi site (Fig. 1) was selected because it presents some economic, technic, operational and morphologic priorities. In adition, the construction of the landfill in Zharresi is in sinergy with the Marinza oily field recovery.

\subsection{Phase 3. Final study (Patos-Marinza site)}

The geology of the site area consists mainly of Pliocene mollasic deposits which according to the lithology belong to two different suites: Helmesi and Rrogozhina. The Helmesi suite, that is 100 to $200 \mathrm{~m}$ thick, consists mainly of massive grey claystone intercalated by scarce and thin sandstone layers (4-5 $\mathrm{cm}$ to $20-30 \mathrm{~cm}$ thickness). The Rrogozhina suite consists mainly of sandstone and conglomerate with subordinate claystoneintercalations. The apparent thickness of Rrogozhina suite on the site varies from $50 \mathrm{~m}$ to $100 \mathrm{~m}$.

Some Quaternary soil formations of the diluvium - proluvium and eluvium types are also present. The diluvium soils are found along slopes and on the valley and consist of silt and clay mixed with sand. They are $0.5-1 \mathrm{~m}$ to $5-6 \mathrm{~m}$ thick. The proluvium soils spread along the stream of the valley and are represented by mixtures of silt and clay which in turn are intercalated with sand and gravel layers. Their thickness ranges $2-6 \mathrm{~m}$. The eluvium soils represent the weathering crust of the basement rocks. They are found on the uppermost part of the basement rocks. Their thickness ranges $1-3.5 \mathrm{~m}$.

From the geotechnical point of view the area under investigation consist of soils and rocks. The soils are represented by silt, silty clay, clay, sand and mixture of gravel and sand with silt (Fig. 3). The soft rocks consist mostly of siltstone and claystone with scarce and thin sandstones. Based on both, field works and laboratory tests, 11 soil and rock layers were distinguished in a total thickness of $15 \mathrm{~m}$ (Fig. 3). According to the following geotechnical parameters: internal friction angle, cohesion, deformation module, bulk density etc., the soils of layer number 2, 3, 4 and 6 result to be geotechnically problematic (refer to the soil investigation report). For this reason they must be taken into consideration during the landfill design.

Two types of groundwater are outlined in the site area: the upper level - groundwater (hygroscopic water) and underground water (free water). The groundwater level as measured in the performed boreholes ranges from $1.5 \mathrm{~m}$ to $2.5 \mathrm{~m}$ from surface. These levels are highly influenced by rainfall 
regime and, because the measurements were performed in wet season, they can be considered as the highest levels.

The underground water is related to three rock types, which can be considered as three different aquifer types:

1. Conglomerate and sandstone formations of Rrogozhina suite. They are placed on the NW side of the valley. Their hydraulic conductivity varies from 0.2 to $7.0 \mathrm{~m} /$ day. The above water-bearing sandstones and conglomerates remain outside of the landfill area. For this reason apart from their moderate to high permeability they do not represent any inconvenience for the landfill construction.

2. Scarce and thin sandstone layers intercalated with Helmesi clay formation. The measured values of hydraulic permeability $(\mathrm{K})$ reach up to $2 \times 10^{-6} \mathrm{~m} / \mathrm{sec}$. These values are slightly higher than the recommended ones $\left(1 \times 10^{-9} \mathrm{~m} / \mathrm{sec}\right)$. For this reason their casual presence under the landfill liner must be technically considered during the landfill design.

3. Quaternary formations of the proluvium and diluvium type, which consist of sand and gravel with high content of clay material. These formations are placed along the axis of the valley. Because of the mixture with large quantities of clay and silt materials, their values of hydraulic permeability range from $2 \times 10^{-5}$ to $2 \times 10^{-7} \mathrm{~m} / \mathrm{sec}$, which are considered slightly higher than the permitted value $\left(1 \times 10^{-9} \mathrm{~m} / \mathrm{sec}\right)$.

The hydro monitoring phase of the project, that started immediately after the completion of the soil investigation works, lasted about five months. The ground water levels were measured every two weeks. The uppermost ground water level was measured on March 01, 2006 in the well SM8, whereas the lowermost one was measured several times in well SM1 (Table 1). Based on the results of hydromonitoring, the following consideration can be given:

1. There is an apparent difference of the underground waters levels between two wells in a couple (SM1 - SM2, SM3 - SM4) (Fig.4.a). This means that there is no hydraulic communication between two wells in a couple, or it is drastically low. Two possible reasons can be considered for explaining this phenomenon: i) the soil composition between two wells is dominated by clay fraction, that, in turn, makes these formations more impermeable, ii) the water bearing formations (sand and gravel) are not continuous. Anyway, the soil investigation data are in favor of the first possibility.

Table 1 - Results of hydromonitoring

\begin{tabular}{|c|c|c|c|c|c|c|c|c|c|}
\hline \multirow{2}{*}{$\begin{array}{c}\text { Well } \\
\text { number }\end{array}$} & \multicolumn{9}{|c|}{ Ground Water Levels (m) } \\
\cline { 2 - 10 } & 27.12 .05 & 16.01 .06 & 03.02 .06 & 20.02 .06 & 01.03 .06 & 16.03 .06 & 31.03 .06 & 16.04 .06 & 02.05 .06 \\
\hline SM1 & -12.7 & -13.5 & -13.8 & -13.8 & -13.7 & -13.7 & -13.6 & -13.8 & -13.8 \\
\hline SM2 & -4.9 & -2.7 & -2.2 & -2.6 & -2.7 & -2.7 & -2.8 & -2.9 & -3.0 \\
\hline SM3 & -3.9 & -3.8 & -3.8 & -3.6 & -3.4 & -3.5 & -3.5 & -3.7 & -3.8 \\
\hline SM4 & -9.9 & -10.5 & -11.1 & -9.4 & -8.8 & -9.0 & -8.9 & -9.2 & -9.2 \\
\hline SM5 & -5.7 & -6.5 & -8.6 & -8.6 & -8.8 & -8.8 & -8.5 & -8.8 & -8.7 \\
\hline SM6 & -10.8 & -11.7 & -8.0 & -8.0 & -7.8 & -8.1 & -8.0 & -8.2 & -8.0 \\
\hline SM7 & -8.3 & -9.2 & -9.0 & -6.8 & -5.8 & -6.3 & -6.1 & -6.2 & -6.2 \\
\hline SM8 & -7.1 & -4.9 & -5.4 & -4.4 & -2.7 & -3.2 & -2.9 & -3.2 & -3.1 \\
\hline
\end{tabular}

2. The wells have intersected two water-bearing layers: the upper layer consisting of gravel and sand, whereas the lower one is represented by sandstone. It could be expected that, the upper ground water levels correspond to gravely layer, while the lower ones correspond to the sandstone. 
3. There is no general trend in the ground water level variation through time. In fact, in the couples SM1-SM2 and SM3-SM4, the upper level firstly tends to be increased, then it was gone slightly down, probably, in agreement with raining quantity variations. The variation trend of the lower levels tends to be slightly different, but following the upper one to some extents.

4. In the couple SM5-SM6 (Fig. 4b), a complete hydraulic communication between the wells was reached after the third measurement. The communication was maintained all over the monitoring phase.

5. A drastic increase of the ground water level was observed in wells SM7 and SM8 during the measurement on March 01, 2006. Because the lower levels correspond to lower sandstone, any ground water increase could be correlated with upper gravel contribution, especially during the high raining season.

During the hydro monitoring of the landfill site, three water samples were taken: from the ground water, surface water and Zharresi river water, respectively. The water samples were tested for both main physical and chemical parameters and some trace elements. The less mineralized waters belong to surface water which are just raining waters. For this reason, it would be expected these waters present a weekly acid $\mathrm{pH}$. The alkaline trend of them can be caused by the solution process of the clay and carbonate materials of the valley. In favor of this opinion is the slightly alkaline value of the ground water $\mathrm{pH}$.

\section{Figure 3 - Geotechnical log of the boring (Zharresi site)}

With respect to hardness and/or water mineralization, all three waters seems to be non-mineralized waters, whereas the $\mathrm{pH}$ is almost neutral with a weakly alkaline trend. The high content of $\mathrm{SO}_{4}$ in surface and river waters it is unusually. It could be related with the immense air-soil-water 
contamination of the region due to the oil industry activity. Sulfur represents an undesirable toxic elements of Patos-Marinza oil.

a) Variation of the underground level through time (SM3-SM4)

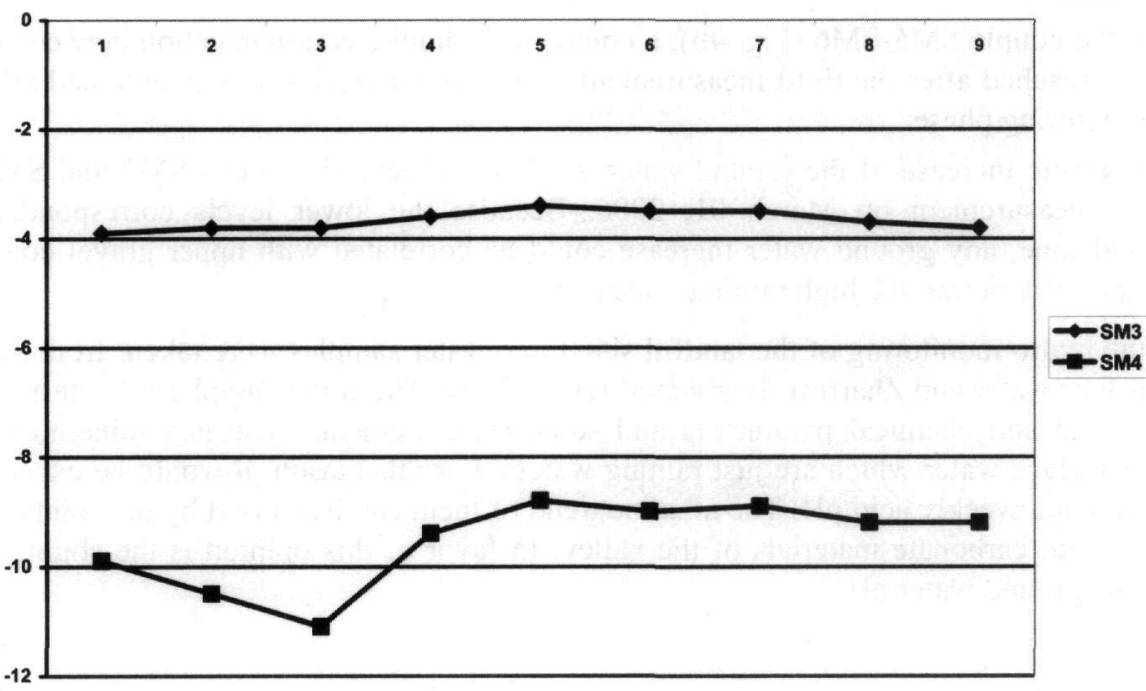

b) Variation of the underground water levels (SM5-SM6)

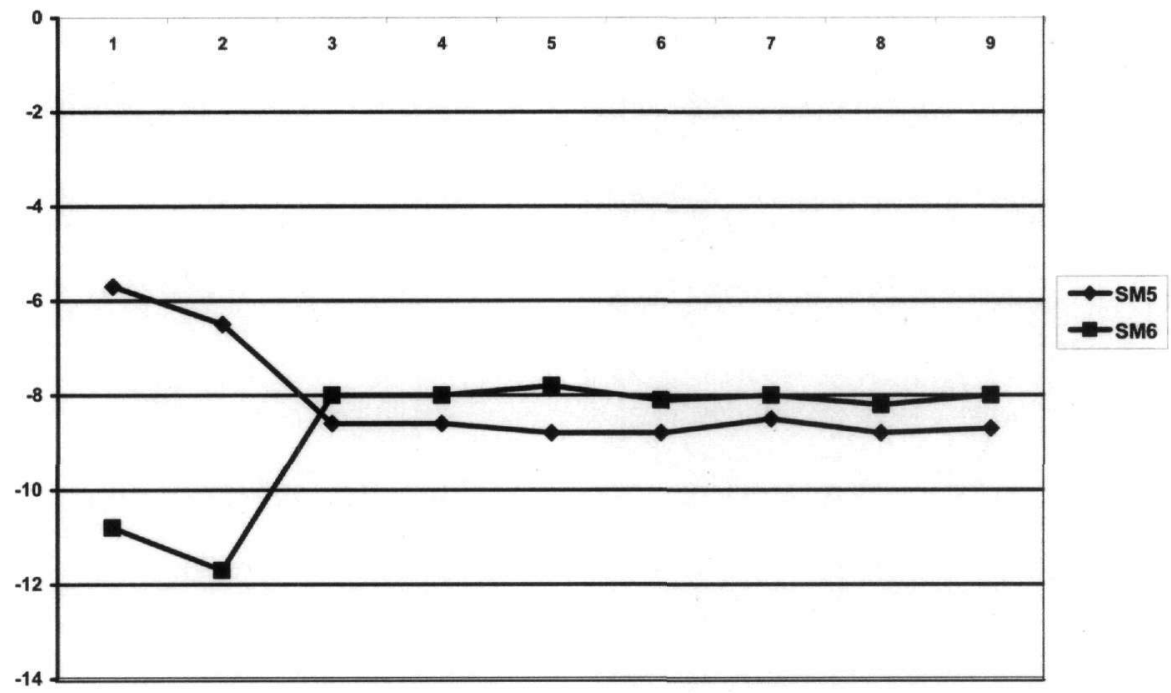

Figure 4 - Underground water level variation through time

In general, all analysed trace elements from three samples show low contents, just near to their natural background. This means that there is no source of industrial contamination, with respect to the above trace elements, in the region. In particular, the ground waters show the lowest contents. The surface waters show a slightly increase relative to rive waters. In fact, it could be expected the opposite. In conclusion, all three waters can be considered free-waters from the heavy metals.

\section{Conclusion}


In Albania occur nine historical hot spots which continue to present a negative environmental impact in the region of their occurrence. In order to reduce this impact to environment, an EU project for the design of a hazardous waste landfill was approved. The geological-geophysical survey, that passes through three phases, anticipated the design phase of the landfill. The geological survey of the first phase found the mostly suitable clayey zones which belong to Miocene-Pliocene clays of the Jonian zone and western Adriatic depression of Albania. The more detailed geological-geophysical study of the second phase focused on three sites: Kutallia, Helmesi and Zharresi. The geophysical methods helped to understand the possible heterogeneities across the general geological structure and the variation of the lithology with depth. Finally, the soil investigation works and hydromonitoring of the ground water levels found that the clays of Zharresi site are suitable for the landfill design.

\section{References}

Beqiraj, A., Hyseni, A., Bejleri, A., et al., 2006. Quantitative and qualitative evaluation of the Rrogozhina aquifer, western Albania, Science Accademy of Albania, 95pp. (in Albanian)

Bray, J.D., Augello, A.J., Leonards, G.A., Repetto, P.C., and Byme, R.J., 2006. Seismic stability procedure for solid waste landfill, Journal of Geotechnical Engineering, vol. 121, No 2.

Geological Map of Albania, 2005. scale 1:200 000, Monography, 264pp.

Hyseni, A., 1995. Tectonic structures and geodynamic evaluation of Pliocene formations, Preadriatic western depression, PhD Thesis, FGJM, Tirane, 157pp.

Lee, G.F., and Jones-Lee, A., 1996. Permitting of New Hazardous Waste Landfills and Landfill Expansions: A Summary of Public Health, Groundwater Resource and Environmental Issues, Report of G. Fred Lee \& Associates, E1 Macero, CA.

Matache, M., Rolylowics, L., Ropata, M., and Capota, P., 2004. Landfills impact on the environment quality, SF. Gheorghe, Covasna country, 1997.

RAMBOLL-ERM Consortium, 2003. Support to waste management in Kilingrad Oblast. Geological Analyses of the proposed landfill site. 